\title{
Pole Level Mangrove Analysis as a Conservation Effort of the Coastal Mangrove Forest of Langsa City
}

\author{
Andri Yusman Persada* \\ Department of Biology, Faculty of Engineering \\ Universitas Samudra \\ Langsa, Indonesia \\ *andri.persada@unsam.ac.id
}

\author{
M. Taufik Rahmadi \\ Department of Geography Education \\ Universitas Negeri Medan \\ Langsa, Indonesia
}

\author{
Ayu Suciani \\ Department of Geography \\ Universitas Samudra \\ Langsa, Indonesia
}

\begin{abstract}
Mangroves are ecosystems that play an important role both ecologically and economically. One of the mangrove forests in Indonesia is The Coastal Mangrove Forest of Langsa City. Human activities and over-development can lead to a decline in the area and reduce mangrove diversity in the future. The purpose of this study was to measure species of mangroves at pole level in order to know the types of mangroves in the future and the management that can be planned as an effort to conserve mangroves in Langsa City. The survey method using plot of $20 \mathrm{x}$ 20 randomly at three sampling points. The results showed 5 types of mangroves at the pole level, namely Avicennia alba, Bruguiera gimnorrhiza, Ceriops decandra, Rhizophora mucronata, and Xylocarpus molucensis. Avicennia alba is a species that has the highest Importance Index value, namely $84.02 \%$.
\end{abstract}

\section{Keywords—ecology, vegetation analysis, mangroves}

\section{INTRODUCTION}

Mangrove are the dominant vegetation in coastal areas. Mangrove are also known as mangroves [1]. Mangroves are found in low-slope coastal areas, especially in tropical and subtropical areas [2]. This vegetation has characteristics that are able to adapt to environmental changes. One of the changes that occurs is the waterlogging by the tides of the sea water. Mangroves are able to adapt to high salinity levels during high tide and can adapt to low traffic levels during low tide. Mangroves have zonation based on the location from the coast to the land. The structure and composition of mangroves are influenced by interactions that occur in the ecosystem, including tides and human activities.

Mangroves are ecosystem that has many functions for coastal areas, especially to maintain the balance and sustainability of coastal and coastal ecosystems [3-5]. Mangroves also have an ecological function as a protection for coastal areas from sea waves and biota habitats. Mangroves also protect against catastrophic events such as tsunamis and tropical cyclones [3,6]. In addition, mangroves are a feeding ground, spawning ground and nursery ground for various biota which have high economic value $[3,7,8]$. The ecological benefits of mangroves are not only for the biota in the area, but also used by migratory birds. Mangroves are used as a stopover area and a place to find food during migration [9]. In addition, mangroves also have social and economic functions in the development of coastal areas in the form of processed products, both timber and non-timber products $[3,7,10]$.

One of the mangroves in Indonesia is the coastal mangrove forest in Langsa City. This mangrove forest is \pm 7,000 ha. There is a continuous development of coastal areas, especially as a tourist area in the Langsa City Mangrove Forest, it is feared that it will reduce the diversity and areas of mangroves. This occurred in Mangrove Forests in East Aceh District, where observations using OLI Landsat 8 imagery showed that the mangrove area in East Aceh has experienced a significant reduction in 10 years [11]. Coastal development could potentially reduce mangrove diversity in the future. The presence of mangrove forests in the future depends on the diversity of mangrove species at the pole level.

The pole level is the growth form of mangroves before becoming mangrove trees as a constituent of vegetation [12]. Human activities to fulfill their needed and development of coastal areas that do not maintain sustainability will eliminate certain mangrove species, especially at the pole level. Previous research obtained results of 4 species of mangroves at the tree level [13]. However, this study had not fully analyzed the mangroves at the pole level and their management for the conservation of mangrove forests in Langsa City. Based on this, the purpose of this study was to determine the types of mangroves at the pole level as a prediction of mangrove forest types in the future. In addition, this research aimed to provide 
mangroves conservation efforts in the future. The results of this study are expected to be taken into consideration in making policies for the development of mangrove forests in Langsa City.

\section{METHODS}

This research was conducted in the Langsa City mangrove forest from August to September 2020. The location point selection was determined based on the landscape shape of the Langsa City mangrove forest. Determination of the location using purposive sampling, namely the selection of locations based on a line from the end of the land which is directly adjacent to the waters to the center of the land (Table 1). This study used a combination of transects and plots in determining the location $[14,15]$.

TABLE I. SITE LOCATION

\begin{tabular}{|c|c|c|}
\hline Location & Coordinate & Information \\
\hline Station 1 & $\begin{array}{l}\mathrm{N} 4^{\circ} 32^{\prime} 37.5^{\prime \prime} \\
\mathrm{E} 98^{\circ} 02^{\prime} 15.9^{\prime \prime}\end{array}$ & The location closest to the sea \\
\hline Station 2 & $\begin{array}{l}\mathrm{N} 4^{\circ} 32^{\prime} 20.0 \\
\text { E } 98^{\circ} 02^{\prime} 08.2\end{array}$ & The location is more inland \\
\hline Station 3 & $\begin{array}{l}\mathrm{N} 4^{\circ} 30^{\prime} 34.7^{\prime \prime} \\
\mathrm{E} 98^{\circ} 00^{\prime} 21.3^{\prime \prime}\end{array}$ & $\begin{array}{l}\text { The location closest to the } \\
\text { mainland }\end{array}$ \\
\hline
\end{tabular}

The plot used was $20 \mathrm{~m} \times 20 \mathrm{~m}$ in size. Plot taking starts from the tip of the land to the mainland with two replications for each location point. In each plot, the mangrove species will be counted at the pole level (figure 1).
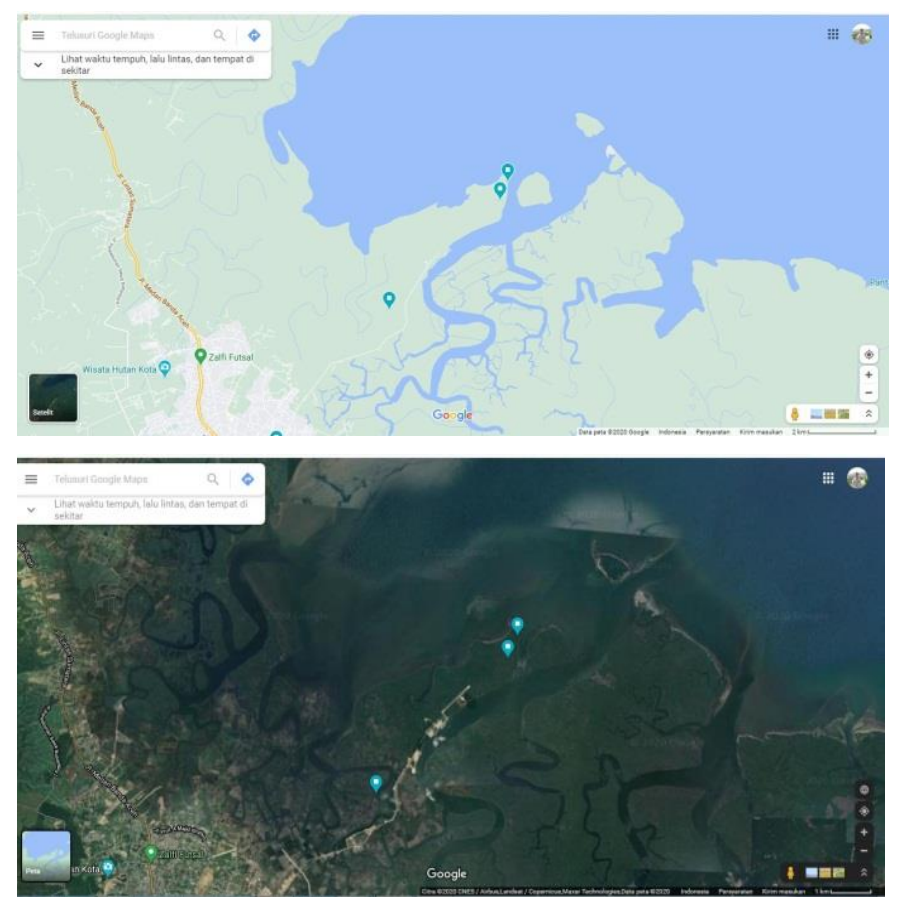

Fig. 1. Station of research.
Station (location) for sampling is taken randomly from the direction of the ocean to the land. There are three stations in this study, namely Station 1, Station, and Station 3. Station 1 is a station that is directly adjacent to the sea/waters, Station 2 is the middle part and Station 3 is the closest location to the mainland. Station 1 is the location closest to the sea. At this location, human activities are not directly related to the mangrove conditions in Langsa City. At Station 1, the community uses it more as a shelter, a place to look for marine life on the coast. Station 2 is a location that is more towards the mainland. This location is close to human activities such as mangrove forest tourism in Langsa City. Station 3 is the location that leads to the mainland. This location is widely used by the community as a pond.

The tools and materials used in this study include GPS, pegs, raffia ropes, hanging labels, collection boxes, books and stationery, ziplock plastic, and $70 \%$ alcohol. The data obtained were then analyzed to determine the vegetation structure at the pile level including density, relative density, frequency, relative frequency, and important value index.

Data analysis using excel with the formula:

$$
\text { density }=\frac{\text { Number of individual count }}{\text { Area }}
$$

$$
\text { Relative density }=\frac{\text { Density Species A }}{\text { Total density }} \times 100
$$

$$
\text { Frequency }=\frac{\text { Number of plots found } A \text { species }}{\text { Sum of all sampling point plots }}
$$

$$
\begin{gathered}
\text { Frequency Relative }=\frac{\text { Frequency Species } A}{\text { Total Frequency }} \\
\mathrm{INP}=\mathrm{DR}+\mathrm{FR}
\end{gathered}
$$

The importance value index is a quantitative parameter that can be used to indicate the level of dominance of vegetation types [16].

\section{RESULTS AND DISCUSSION}

\section{A. Pole Level Mangrove}

Sapling/pole is a form of growth from plants. There are five mangrove poles found in the research location, consisting of three families, namely Avicennia alba, Bruguiera gimnorrhiza, Ceriops decandra, Rhizophora mucronata, and Xylocarpus molucensis. The families found in the research location were Avicenniaceae, Rhizophoraceae, and Meliaceae family. The family that has the most species found at the research location is the family Rhizophoraceae. This is because the 
Rhizophoraceae family has a wide distribution, from the water's edge to the mainland. This is because it is supported by various factors, one of which is the type of root. Rhizophoraceae has various types of roots, namely supporting roots, knee roots, and aerial roots. Supporting root is a type of root-like chicken claw that is owned by mangroves on the beach [17]. This root serves to strengthen the mangroves from the wind and the waves crashing from the shore. Therefore, the Rhizophoraceae family was found at all stations in the study location.

Sapling/pole is a form of growth from plants. There are five mangrove poles found in the research location, consisting of three families, namely Avicennia alba, Bruguiera gimnorrhiza, Ceriops decandra, Rhizophora mucronata, and Xylocarpus molucensis. The families found in the research location were Avicenniaceae, Rhizophoraceae, and Meliaceae family. The family that has the most species found at the research location is the family Rhizophoraceae. This is because the Rhizophoraceae family has a wide distribution, from the water's edge to the mainland. This is because it is supported by various factors, one of which is the type of root. Rhizophoraceae has various types of roots, namely supporting roots, knee roots, and aerial roots. Supporting root is a type of root-like chicken claw that is owned by mangroves on the beach [17]. This root serves to strengthen the mangroves from the wind and the waves crashing from the shore. Therefore, the Rhizophoraceae family was found at all stations in the study location.

TABLE II. SPECIES FOUND AT THE STUDY SITE

\begin{tabular}{|l|l|l|l|l|l|}
\hline No & $\begin{array}{l}\text { Scientific } \\
\text { name }\end{array}$ & \multicolumn{1}{|c|}{ Famili } & $\begin{array}{c}\text { Station } \\
\mathbf{1}\end{array}$ & $\begin{array}{c}\text { Station } \\
\mathbf{3}\end{array}$ & $\begin{array}{c}\text { Station } \\
\mathbf{3}\end{array}$ \\
\hline 1 & $\begin{array}{l}\text { Avicennia } \\
\text { alba }\end{array}$ & Avicenniaceae & Present & Present & Present \\
\hline 2 & $\begin{array}{l}\text { Bruguiera } \\
\text { gimnorrhiza }\end{array}$ & Rhizophoraceae & Absent & Absent & Present \\
\hline 3 & $\begin{array}{l}\text { Ceriops } \\
\text { decandra }\end{array}$ & Rhizophoraceae & Absent & Absent & Present \\
\hline 4 & $\begin{array}{l}\text { Rhizophora } \\
\text { mucronata }\end{array}$ & Rhizophoraceae & Present & Present & Present \\
\hline 5 & $\begin{array}{l}\text { Xylocarpus } \\
\text { molucensis }\end{array}$ & Meliaceae & Absent & Absent & Present \\
\hline
\end{tabular}

Based on Table 2, Avicennia alba Included in the Avicenniaceae family are species that have the highest Relative Density, Relative Frequency and Index of Importance of mangrove poles at the research location. This is like a study Putra et al., [18] that the Avicenniaceae family also has the highest value in mangroves and is a pioneer / reclamation plant. This shows the potential that the Avicennia family, especially Avicennia alba, will still exist naturally in the future. At the research location, Avicennia alba was found in all research locations, from the coast to the mainland. This is because Avicennia alba has a high tolerance range and is a pioneer mangrove species [19].

Based on Table 3, the most commonly found mangrove species at the pole stage are Avicennia alba with a relative density of $50.68 \%$ and an IVI value of $84.02 \%$. This can show naturally that the species that will appear in the future is the species Avicennia alba. The mangrove species that had the lowest relative density was Ceriops decandra at $1.37 \%$ with an IVI value of 12.48. This is because Ceriops decandra is one of the rare mangrove species globally.

TABLE III. MANGRove PILES ObTAINED AT THE RESEARCH Site

\begin{tabular}{|c|l|l|l|l|c|}
\hline No & $\begin{array}{c}\text { Scientific } \\
\text { name }\end{array}$ & Famili & KR & FR & INP \\
\hline 1 & $\begin{array}{l}\text { Avicennia } \\
\text { alba }\end{array}$ & Avicenniaceae & 50,68 & 33,33 & 84,02 \\
\hline 2 & $\begin{array}{l}\text { Bruguiera } \\
\text { gimnorrhiza }\end{array}$ & Rhizophoraceae & 8,22 & 11,11 & 19,33 \\
\hline 3 & $\begin{array}{l}\text { Ceriops } \\
\text { decandra }\end{array}$ & Rhizophoraceae & 1,37 & 11,11 & 12,48 \\
\hline 4 & $\begin{array}{l}\text { Rhizophora } \\
\text { mucronata }\end{array}$ & Rhizophoraceae & 34,25 & 33,33 & 67,58 \\
\hline 5 & $\begin{array}{l}\text { Xylocarpus } \\
\text { molucensis }\end{array}$ & Meliaceae & 5,48 & 11,11 & 16,59 \\
\hline
\end{tabular}

\section{B. Distribution and Abundance of Pole Level Mangrove}

1) Station 1: There are two mangrove species at pole level found at location 1, namely Avicennia alba and Bruguiera gimnorrhiza. Avicennia alba has a density of 525 individuals/hectare while Bruguiera gymnorrhiza has a density of 175 individuals/hectare (Figure 2). Avicennia alba has the highest density at location one, indicating that location one is still natural and is a location directly adjacent to the sea [15]. Avicennia alba has a wide tolerance range to salinity. Besides, locations directly adjacent to the sea have low sedimentation. This is following Affandi et al., [20] which states that Avicennia alba is not suitable for high sedimentional locations. Another species found at site 1 is Bruguiera gimnorrhiza. This can be caused by propagules flowing in the direction of the water flow. Allen and Duke [21] stated that Bruguiera gimnorrhiza is viviparous which can be germinated in the parent plant (propagule).

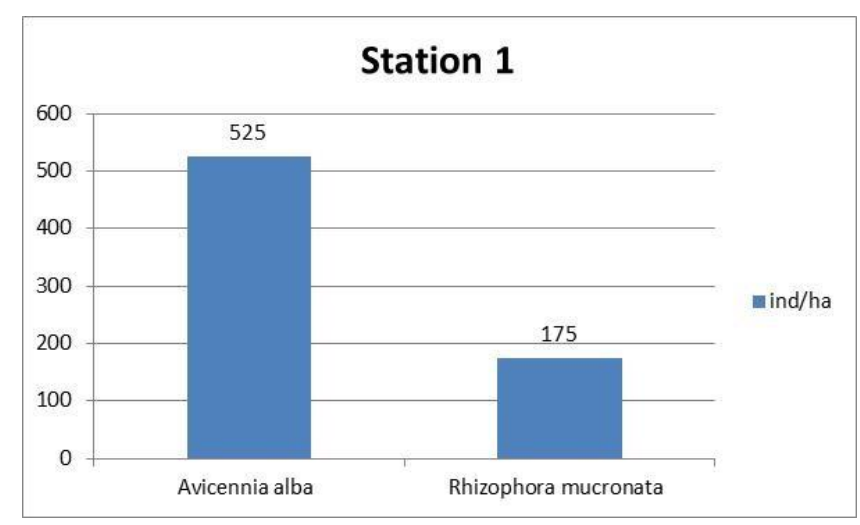

Fig. 2. Densitas pole level mangrove in location 1.

2) Station 2: Station 2 has two pole-level mangrove species, namely Avicennia alba and Bruguiera gimnorrhiza with densities of 250 individuals/hectare and 200 individuals / 
hectare, respectively. The number of species and species is also the same, what is different is the density of each species. At this location, the Bruguiera gimnorrhiza poles increased from 175 individuals/hectare to 200 individuals/hectare. This is because the tolerance range is more suitable for Bruguiera gimnorrhiza which is not directly adjacent to the sea. In contrast, the density of Avicennia alba decreased from 525 individuals/hectare to 250 individuals/hectare (see in figure 3).

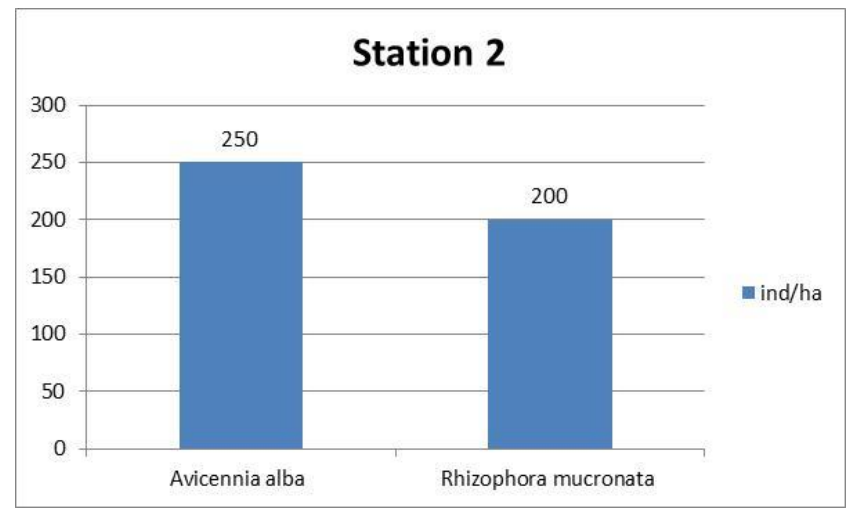

Fig. 3. Densitas pole level mangrove in Location 2.

Station 3 is the station where the most mangrove pole species are found, with five species. The species density at station 3 varied, namely Avicennia alba (200 ind / ha), Bruguiera gimnorrhiza (150 ind / ha), Ceriops decandra (25 ind / ha), Rhizophora mucronata (250 ind / ha), and Xylocarpus molucensis (100 ind / ha). Ha). Rhizophora mucronata has the highest density at location 3 because location 3 is far from the ocean and close to the mainland. This is following Batoll et al., [22] which states that the habitat for Rhizophora mucronata is estuaries, tidal creeks.

\section{CONCLUSION}

There were five types of mangrove poles found at the research location, namely Avicennia alba, Bruguiera gimnorrhiza, Ceriops decandra, Rhizophora mucronata, and Xylocarpus molucensis. Avicennia alba has the highest Importance Value Index, which was $84.02 \%$. This showed that naturally Avicennia alba has the potential to be present in the future. Ceriops decandra is a mangrove species that has the lowest Importance Value Index of $12.48 \%$

\section{ACKNOWLEDGMENT}

We gratefully acknowledgment all those who have helped the author in this research. This research was funded by the Ocean University Excellence Basic Research Grant in 2020 with contract number 501 / UN54.6 / PG / 2020.

\section{REFERENCES}

[1] N. Matsui, W. Meepol, and J. Chukwamdee, "Soil Organic Carbon in Mangrove Ecosystems with Different Vegetation and Sedimentological Conditions," J. Mar. Sci. Eng., vol. 3, no. 4, pp. 1404-1424, 2015.
[2] C. Kusmana, S. Wilarso, I. Hilwan, P. Pamoengkas, C. Wibowo, T. Tiryana, A. Triswanto, and H. Yunasfi, "Teknik Rehabilitasi Mangrove," Fak. Kehutan. IPB. Bogor, vol. 177, 2003.

[3] M. Ilman, I.T.C. Wibisono, and I.N.N. Suryadiputra, "State of the Art Information on Mangrove Ecosystems in Indonesia," Wetl. Int. Program. Bogor, 2011.

[4] C. Marchand, "Soil Carbon Stocks and Burial Rates along a Mangrove Forest Chronosequence (French Guiana)," For. Ecol. Manage., vol. 384, pp. 92-99, 2017.

[5] T.P. Nguyen and K.E. Parnell, "Gradual Expansion of Mangrove Areas as an Ecological Solution for Stabilizing a Severely Eroded Mangrove Dominated Muddy Coast,” Ecol. Eng., vol. 107, pp. 239-243, 2017.

[6] D.M. Alongi, "Mangrove Forests: Resilience, Protection from Tsunamis, and Responses to Global Climate Change," Estuar. Coast. Shelf Sci., vol. 76, no. 1, pp. 1-13, 2008.

[7] F.M.A. Barbosa, C.C. Cuambe, and S.O. Bandeira, "Status and Distribution of Mangroves in Mozambique," South African J. Bot., vol 67, no. 3, pp. 393-398, 2001.

[8] M.M. Igulu, I. Nagelkerken, M. Dorenbosch, M.G.G. Grol, A.R Harborne, I.A. Kimirei, P.J. Mumby, A.D. Olds, and Y.D. Mgaya, "Mangrove Habitat Use by Juvenile Reef Fish: Meta-Analysis Reveals That Tidal Regime Matters More than Biogeographic Region," PLoS One, vol. 9, no. 12, p. e114715, 2014.

[9] J. Howes, D. Bakewell, and Y.R. Noor, Panduan studi burung pantai. Wetlands International, 2003.

[10] C. Kusmana and S. Sukristijiono, "Mangrove Resource Uses by Local Community in Indonesia," J. Pengelolaan Sumberd. Alam dan Lingkung. (Journal Nat. Resour. Environ. Manag., vol. 6, no. 2, p. 217 , 2016

[11] A. Suciani, M. Rahmadi, M. Damanik, and A. Nurman, "Utilization of Landsat Images for Identification and Analysis of Changes in the Mangrove Forest Area in East Aceh District,” Proc. 2nd Int. Conf. Soc. Sci. Interdiscip. Stud., 2019

[12] M. F. Fachrul, Metode Sampling Ekologi. Jakarta: Indonesia: Jakarta: Bumi AKsara, 2007.

[13] S.P. Febri, A. Putriningtias, and T.M. Faisal, "Kondisi Vegetasi Hutan Mangrove Kuala Langsa Kota Langsa, Aceh,” J. Ilm. Samudra Akuatika, vol. 1, no. 1, pp. 12-19, 2017.

[14] T.S. Djohan, "Distribution and Abundance of Mangrove Vegetation in the Disturbed Ecosystem of Segara Anakan, Central Java (Distribusi Dan Kemelimpahan Vegetasi Bakau Di Ekosistem Hutan Rusak Segara Anakan Jawa Tengah)," J. Mns. dan Lingkung., vol. 19, no. 3, pp. 294 $302,2012$.

[15] W. Isroni, R.A. Islamy, M. Musa, And P. Wijanarko, "Species Composition and Density of Mangrove Forest in Kedawang Village, Pasuruan, East Java, Indonesia,” Biodiversitas J. Biol. Divers., vol. 20 no. $6,2019$.

[16] Indriyanto, Ekologi Hutan. Jakarta: Indonesia: Jakarta: Bumi Aksara, 2006.

[17] B.S. Tumangger, "Identifikasi Dan Karateristik Jenis Akar Mangrove Berdasarkan Kondisi Tanah Dan Salinitas Air Laut Di Kuala Langsa," Biol. SAMUDRA, vol. 1, no. 1, pp. 9-16, 2019.

[18] C.A. Putra, Z. Arico, K. Triwibowo, and N. Azmi3, "Studi Biodiversitas Burung Air Dan Hutan Mangrove Sebagai Potensi Ekowisata Di Bagan Percut, Kabupaten Deli Serdang, Propinsi Sumatra Utara," J. Resolusi Konflik, CSR Dan Pemberdaya., vol. 5, no. 1, pp. 30-42, 2020

[19] A. Mughofar, M. Masykuri, and P. Setyono, "Zonasi Dan Komposisi Vegetasi Hutan Mangrove Pantai Cengkrong Desa Karanggandu Kabupaten Trenggalek Provinsi Jawa Timur,” J. Pengelolaan Sumberd. Alam dan Lingkung. (Journal Nat. Resour. Environ. Manag., vol. 8, no. 1, pp. 77-85, 2018.

[20] N.A.M. Affandi, B. Kamali, R. Mz, N.M. Tamin, and R. Hashim, "Early Growth and Survival of Avicennia Alba Seedlings under Excessive Sedimentation," Sci. Res. Essays, vol. 5, no. 18, pp. 2801-2805, 2010.

[21] J.A. Allen and N.C. Duke, "Bruguiera Gymnorrhiza (Large-Leafed Mangrove),” Elev. CR Species Profiles Pacific Isl. Agroforestry. Perm. Agric. Resour. (PAR), Hōlualoa, Hawai'i, 2006.

[22] N. Batool, N. Ilyas, and A. Shahzad, "Asiatic Mangrove (Rhizophora Mucronata)-An Overview," Eur. Acad. Res., vol. 2, no. 3, pp. 3348 3363,2014 